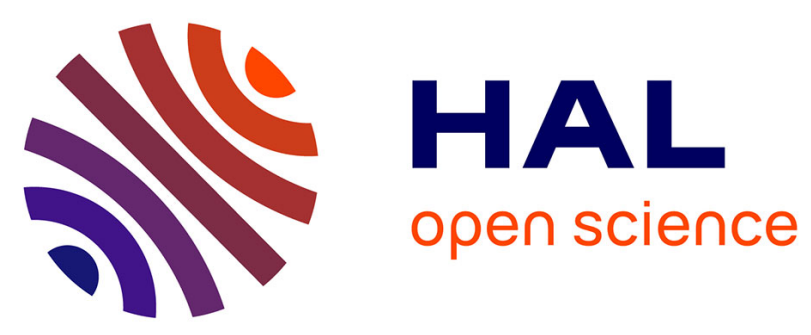

\title{
PROPHYLAXIS THERAPY IN HAEMOPHILIA A: CURRENT SITUATION IN SPAIN
}

Felix Lucia, José Antonio Aznar, Lydia Abad-Franch, Rebeca Rubio Escuin,

Victor Jimenez-Yuste, Rosario Perez Garrido, Francisco Javier Batlle, Ina Balda, Gabriela Alperovich, Rafael Parra

\section{To cite this version:}

Felix Lucia, José Antonio Aznar, Lydia Abad-Franch, Rebeca Rubio Escuin, Victor Jimenez-Yuste, et al.. PROPHYLAXIS THERAPY IN HAEMOPHILIA A: CURRENT SITUATION IN SPAIN. Haemophilia, 2010, 17 (1), pp.75. 10.1111/j.1365-2516.2010.02378.x . hal-00599532

\section{HAL Id: hal-00599532 https://hal.science/hal-00599532}

Submitted on 10 Jun 2011

HAL is a multi-disciplinary open access archive for the deposit and dissemination of scientific research documents, whether they are published or not. The documents may come from teaching and research institutions in France or abroad, or from public or private research centers.
L'archive ouverte pluridisciplinaire HAL, est destinée au dépôt et à la diffusion de documents scientifiques de niveau recherche, publiés ou non, émanant des établissements d'enseignement et de recherche français ou étrangers, des laboratoires publics ou privés. 


\section{Haemophilia momanamemasurion \\ World Federation of Hemophilia}

\section{PROPHYLAXIS THERAPY IN HAEMOPHILIA A: CURRENT SITUATION IN SPAIN}

\begin{tabular}{|r|l|}
\hline Journal: & Haemophilia \\
\hline Manuscript ID: & HAE-00061-2010 \\
\hline Manuscript Type: & Original Article \\
\hline Datho Submitted by the & 01-Jun-2010 \\
\hline Complete List of Authors: & $\begin{array}{l}\text { Lucia, Felix; Hospital Miguel Servet, Servicio de Hematologia } \\
\text { Aznar, José Antonio; Hospital Universitario LA FE, Unidad de } \\
\text { Trombosis y Hemostasia } \\
\text { Abad-Franch, Lydia; Hospital Universitario La Fe, Unidad de } \\
\text { Trombosis y Hemostasia } \\
\text { Rubio Escuin, Rebeca; Hospital Miguel Servet, Servicio de } \\
\text { Hematologia } \\
\text { Jimenez-Yuste, Victor; Hospital Universitario La Paz, Haematology } \\
\text { Perez Garrido, Rosario; University Hospital Virgen del Rocio } \\
\text { Batlle, Francisco; Complejo Hospitalario A Coruña, Haematology } \\
\text { Balda, Ina; Hospital Dr Negrin, Servicio de Hematologia y } \\
\text { Hemoterapia } \\
\text { Alperovich, Gabriela; Pfizer, Medical Department } \\
\text { Parra, Rafael; Hospital Universitari Vall d'Hebron, Haemophilia Unit }\end{array}$ \\
\hline keywords: & \begin{tabular}{l} 
haemophilia A, prophylaxis, epidemiology, Spain \\
\hline \hline
\end{tabular} \\
\hline \hline
\end{tabular}

\section{S ScholaroNE"


TITLE: PROPHYLAXIS THERAPY IN HAEMOPHILIA A: CURRENT SITUATION IN SPAIN

\section{AUTHORS:}

- José Félix Lucía ${ }^{1}$

- José Antonio Aznar ${ }^{2}$

- Lydia Abad-Franch ${ }^{2}$

- R. Rubio Escuin ${ }^{1}$

- Víctor Jiménez-Yuste ${ }^{3}$

- Rosario Pérez ${ }^{4}$

- Javier Batlle ${ }^{5}$

- Ignacia Balda $^{6}$

- Gabriela Alperovich ${ }^{7}$

- Rafael Parra ${ }^{8}$

\section{ON BEHALF OF THE SPANISH HAEMOPHILIA} EPIDEMIOLOGICAL STUDY WORKING GROUP

${ }^{1}$ Department of Haematology, University Hospital Miguel Servet, Zaragoza.

${ }^{2}$ Thromboses and Haemostasis Unit. University Hospital La Fe. Valencia.

${ }^{3}$ Congenital Coagulopathies Unit, University Hospital La Paz. Madrid.

${ }^{4}$ Haemophilia Unit, University Hospital Virgen del Rocío, Sevilla.

${ }^{5}$ Department of Haematology, University Hospital Juan Canalejo, A Coruña.

${ }^{6}$ Department of Haematology, University Hospital Doctor Negrín, Las Palmas de Gran Canaria.

${ }^{7}$ Medical Department, Pfizer, Spain

${ }^{8}$ Haemophilia Unit, University Hospital Vall d’Hebrón, Barcelona.

\section{CORRESPONDENCE: Dr. José F. Lucía}

Haemostasis Unit, Department of Haematology,

University Hospital Miguel Servet

Paseo Isabel la Católica ${ }^{\circ} 1$

50009-Zaragoza.- Spain.

Telephone number: +34976765500

Fax number: +34 976566234

e-mail address: jflucia@salud.aragon.es

KEY WORDS: Haemophilia A, prophylaxis, epidemiology, Spain

\section{Running title: Prophylaxis in haemophilia A in Spain}




\section{SUMMARY}

The Spanish Epidemiological Study in Haemophilia carried out in 2006 enrolled 2400 patients (2081 -86.7\%- with haemophilia A (HA) and 319 -13.3\%- with haemophilia B (HB)); 465 of them (19.4\%) were on prophylaxis. These rates were higher in patients with severe haemophilia $(45.4 \%)$ and severe paediatric cases $(72.5 \%)$. Based on the information recorded in this study we analysed the current situation of prophylaxis therapy administered to patients with HA in Spain, as well as their orthopaedic status. Prophylaxis was used in 399 (19.2\%) patients with HA; such prophylaxis was primary (PP) in $20.3 \%$ and secondary (SP) in $75.9 \%$ of cases. Among severe HA patients, 313 (45.9\%) were on prophylaxis (22.3\% on PP and $74.7 \%$ on SP). Taking into account the patients' age, $34.7 \%$ of severe HA adults were on prophylaxis (6\% PP and $92.1 \% \mathrm{SP}$ ) whereas $71.5 \%$ of severe HA paediatric patients (40.5\% PP and $55.4 \% \mathrm{SP})$ received this kind of treatment.

Established haemophilic arthropathy (EHA) was detected in 142 from 313 severe HA patients $(45.3 \%)$ on prophylaxis, but only in $2.9 \%$ of patients under PP versus $59 \%$ of patients receiving SP. There was no EHA in adult severe HA patient on PP, whereas $70.4 \%$ on SP had joint damage $(\mathrm{p}<0.00001)$. Among paediatric severe HA patients, EHA was detected in $3.3 \%$ under PP and $37.8 \%$ under SP $(\mathrm{p}<0.00001)$. In conclusion, our data suggests that an early initiation of prophylaxis avoids EHA in the long term in patients with severe HA. We should emphasize the early onset of prophylaxis regimens.

\section{INTRODUCTION}

A comprehensive epidemiological study aimed to update available information on clinical features of haemophilia patients registered in 51 haemophilia treatment centres throughout the country was carried out in Spain in 2006; from these reports relevant 
clinical and therapeutic information from 2400 patients (2081 -86.7\%- with haemophilia A and $319-13.3 \%$ - with haemophilia B) was recorded. Illness was severe in $32.3 \%$ of patients, moderate in $16.4 \%$, and mild in $51.3 \%$. Adult patients (14 years of age or over) represented $77.2 \%$ of cases [1].

We found that 465/2400 (19.4\%) were on regular prophylaxis. If we consider patients with severe haemophilia, $45.4 \%$ of them were on prophylaxis. Nevertheless, if we consider only paediatric severe patients, $72.5 \%$ were on regular prophylaxis treatment.

Data collected during such study were the basis on which the Spanish Haemophilia Registry was built in 2008; this database comprised information on 2905 haemophilia patients (2518 with haemophilia A and 387 with haemophilia B) from 53 haemophilia treatment centres [2].

On the basis of the information from the Spanish Epidemiological Study [1] we aimed to achieve a deeper knowledge of various issues involved in clinical practice like the real current situation of primary and secondary prophylactic treatment provided to both paediatric and adult haemophilia A (HA) patients in our country, as well as their current orthopaedic status according to the Pettersson score [3] and the implementation of central venous access devices (CVAD) insertion often required for an adequate compliance of therapeutic schedules involving frequent intravenous infusions [4].

\section{MATERIALS AND METHODS}

Data used for our evaluation were obtained from the database made up for the Spanish Haemophilia Epidemiological Study, involving 2081 HA patients registered and managed in 51 haemophilia treatment centres [1].

The degree of severity of haemophilia was sorted according to previously published standard criteria related to FVIII plasma levels as severe $\left(<0.01 \mathrm{U} \mathrm{dL}^{-1}\right)$, moderate $\left(\geq 0.01 \mathrm{U} \mathrm{dL}^{-1}\right.$ to $\left.<0.05 \mathrm{U} \mathrm{dL}^{-1}\right)$ and mild $\left(\geq 0.05 \mathrm{U} \mathrm{dL}^{-1}\right.$ to $\left.0.4 \mathrm{U} \mathrm{dL}^{-1}\right)$ [5]. Patients $\geq 14$ years of age were rated as adults and those $<14$ as paediatric.

Definition of the type of prophylactic treatment was made following the recommendations of the PEDNET group (European Paediatric Network for Haemophilia Treatment) [6] as:

- A primary prophylaxis (APP): Regular continuous (minimum 46 weeks a year) treatment started after the first joint bleed recorded and before the age of 2 years. 
- B primary prophylaxis (BPP): Regular continuous (minimum 46 weeks a year) treatment started before the age of 2 years without any evidence of a previous joint bleed.

- A secondary prophylaxis (ASP): Regular continuous (long term) treatment started after 2 or more joint bleeds recorded or at an age $>2$.

- B secondary prophylaxis (BSP): Intermittent regular (short term) treatment provided in order to cover frequent haemarthroses.

Assessment of joint status was made by visualisation of X-rays of elbows, knees and ankles according to the Pettersson score [3]; scores of $\geq 3$ for any particular joint were consistent with established haemophilic arthropathy (EHA).

Information related to CVAD was focused on particular aspects like catheter duration and incidence of the two most frequent complications associated to their use: infection and thrombosis.

\section{Statistical analysis}

A descriptive analysis was done, using absolute and relative frequencies for qualitative variables and centralization and dispersion measures for quantitative variables. Pearson's Chi-square test (or Fisher's exact test for 2x2 tables, or reason of verisimilitude $m x n$ tables, if necessary) were used to find the relation between qualitative variables. The T Student test or one-factor ANOVA were used for the comparison of continuous variables, if parametric criteria were fulfilled. The statistical significance value has been established at $\mathrm{p}<0.05$.

\section{RESULTS}

Information from 2081 HA patients registered in the Spanish Epidemiological Study was analysed; 682 (32.8\%) of them were patients with severe haemophilia, whereas 290 (13.9\%) and 1109 (53.3\%) were moderate and mild cases respectively. Patients classified as adults accounted for $77.2 \%$ (1607) of the whole series and children 474 $(22.8 \%)$.

\section{Prophylaxis in haemophilia A patient population}

Evaluation of this group of 2081 HA patients showed that $399(19.2 \%)$ of them were on prophylaxis: primary in 81 cases $(20.3 \%)$, secondary in $303(75.9 \%)$ and undetermined in $15(3.7 \%)$. Details are shown in Table 1. 
In the analysis by groups of age and type of treatment we founded the following results (see Table 2):

- Only a minor proportion of adult HA patients $(215 ; 13.4 \%)$ were on prophylactic therapy: primary in $13(6.1 \%)$ and secondary in 196 (92.2\%).

- The rate of paediatric patients on prophylaxis was far higher, as expected (184; $38.8 \%$ ); rates of primary (PP) and secondary prophylaxis (SP) for this age group were $26.9 \%$ (68 cases) and $58.1 \%$ (107 cases) respectively.

\section{Prophylaxis in severe haemophilia A patient population}

Almost half of the 682 severe HA patients $(45.9 \%$; 313) were on prophylactic treatment, either PP (70 cases; $22.3 \%$ ) or SP (234 cases; 74.7\%) (Tables 1 \& 2). Among paediatric patients diagnosed with severe HA $(\mathrm{n}=207)$, prophylaxis was administered to $71.5 \%$ (148 cases): $40.5 \%$ (60 cases) for PP and 55.4\% (82 cases) for SP. Adult severe HA patients (475 subjects, 433 on treatment) were far less frequently on prophylaxis (34.7\%; 165 cases); the vast majority of them followed a SP treatment scheme $(92.1 \%$; 152 cases) and only $6.0 \%$ (10 cases) a PP one (Tables $1 \& 3)$.

Figure 1 reflects the rate of prophylaxis used in the whole Haemophilia A population and in the severe HA patients by age groups.

\section{Joint status}

Assessment of joint status was possible for 1228 of all patients enrolled in the epidemiological study and evidence of EHA was proved for 555 (45.2\%) of them.

Among the 313 severe HA patients receiving prophylaxis, EHA was detected in 142 of them $(45.4 \%)$, but only in $2.9 \%$ of patients under PP versus $59 \%$ of patients receiving SP $(\mathrm{p}<0.001)$ (Table 4).

For all 433 treated severe HA adult patients recorded, EHA was found in $74.4 \%$ (322/433) of them and rates of chronic joint damage were significantly higher for patients receiving on demand treatment $(79.4 \%)$ than for patients receiving prophylaxis with regular factor VIII infusions $(66.1 \%), \mathrm{p}=0.002$. There was no EHA in adult severe HA patient on PP, whereas $70.4 \%$ on SP had joint damage $(\mathrm{p}<0.00001)$ (Table 4). This evaluation was also made in 148 paediatric severe HA patients on prophylaxis. Pettersson scores consistent with EHA were found in $33(22.3 \%)$ of them, but only in $3.3 \%(2 / 60)$ of paediatric severe HA patients on APP or BPP; however signs of chronic joint damage were found in $37.8 \%(31 / 82)$ of children on ASP or BSP $(\mathrm{p}<0.00001)$. 


\section{Type of factor VIII concentrate used for prophylaxis}

Recombinant factor VIII concentrates were administered for prophylaxis to $71.4 \%$ $(285 / 399)$ of HA patients, and plasma derived products were used in $28.6 \%$ of cases $(114 / 399)$ at the time of data collection. Rates of recombinant concentrate use were higher among the patients on PP (87.7\%) than among those on SP (66.7\%).

\section{Frequency of infusions and bleeds}

During the study period mean number of factor VIII concentrate infusions for the 399 HA patients were 3 (SD: 0.76). The mean annual number of bleeds was 1.3 for subjects belonging to the APP subset (range 0-18, SD: 3.14), 1.2 for those on BPP (range 0-8, SD: 1.88), 3.1 for ASP (range 0-78, SD: 8.14) and 4.3 for BSP (range 0-17, SD: 4.85). Mean number of annual bleeding episodes for HA patients on prophylaxis was 2.9 (range 0-78, SD: 6.53).

\section{Infusion routes of factor VIII concentrates}

Factor concentrate was mostly administered through peripheral veins to HA individuals on regular prophylaxis $(87.2 \%)$. Only in $9.5 \%$ of patients a CVAD was required and in $1.7 \%$ of cases both types of venous access were used. Important differences were found in CVAD insertion frequencies between patients on PP (23.4\%) and SP (7.3\%).

Complications associated to the use of CVAD were reported in 29 of 41 (70.7\%) of catheters inserted. Infection was the most common of these complications (11 patients; $37.9 \%$ ) with a rate of 0.73 patient days throughout 2006. No cases of thrombosis were reported. CVAD malfunctioning was recorded in 4 patients $(13.8 \%)$ and some type of minor undetermined complication in almost half of cases $(14 ; 48.3 \%)$. 
DISCUSSION

Our current study aimed to get a real and deep knowledge of the implementation of prophylactic therapy in patients with HA in Spain and to compare this information with that reported in other countries in order to find out any potential differences in clinical practice in this setting which might be susceptible to be improved. However such comparisons are often difficult to make due to heterogeneity in the criteria used for patient definition and classification in the series reported. These differences may largely depend on age cut-offs used, definitions of prophylaxis, dosage intervals prescribed, FVIII:C plasma levels considered for the diagnosis of severity of haemophilia and also type of evaluations used: cross-sectional, retrospective, prospective, etc.

Regarding the rates of HA patients by degree of severity, our series shows a proportion of severe cases of $32.8 \%$, which is similar to that reported in the Canadian (Biss et al; 30.6\%), Swedish (Larsson et al; 30\%) and Dutch (Plug et al; 39\%) studies [7-9]. These figures are significantly higher in other published series of patients from the USA (Butler et al; 53\%) [10], Poland (Windyga et al; 59.7\%) [11] and most recently Japan (Ono et al- 69.5\%-; Taki et al -73.4\%-) [12,13].

Our results show that $19.2 \%$ of HA patients are following some type of prophylaxis treatment, consistently with data published by Biss et al (20.3\%) [7], but not with those reported by Plug et al (29\%) [9]. Rates of prophylaxis available in Japanese series are very surprisingly heterogeneous, considering that they offer information on patients treated in the same country; thus Ono et al [12] report rates of prophylaxis of $67.2 \%$, whereas for Taki et al [13] it is of only $11.6 \%$.

When we focused our analysis on severe HA patients (682 altogether) we found out that almost half of them $(313 ; 45.9 \%)$ were on some type of prophylactic treatment, a rate similar to that reported by Butler et al (44\%) [10] but lower than in the Dutch (Plug et al; 67.6\%) [9] or Canadian series (Biss et al; 62.3\%). Comparison of our data with those in this latter study is difficult to carry out because prophylaxis as considered in this paper refers to factor VIII treatment administered at least once a week during 45 weeks a year, whereas our patients received factor VIII infusions three times a week.

As expected, a lower proportion of our moderate HA patients were on prophylaxis $(22.4 \%)$. Our figures are higher than those from the study by Taki et al (17\%) or Plug et al $(11.9 \%)$. Perhaps physicians involved in haemophilia care should be more aware of the need of prophylactic therapy in some patients affected by moderate haemophilia. 
Blanchette et al [14] reported joint data from American and Canadian paediatric patients; $77 \%$ of their severe HA patients in this group of age (with an age cut-off of 18) were on some sort of prophylaxis treatment consistent with $72.5 \%$ from our epidemiological study (using 14 as a top age for patients being considered as paediatric) after exclusion of undetermined cases. Differences in age cut-offs between both groups must be taken into account when comparing results from both studies. Other authors like Plug et al set this cut-off at the age of 16 and report prophylaxis rates of $86 \%$ for severe HA patients [9]. Great heterogeneity existing in classification of age groups can be an issue when interpreting the results from different studies.

The target prophylaxis rate for paediatric severe HA patients should ideally be $100 \%$ but this goal is virtually impossible to achieve for various reasons: regular venipuncture is difficult for children under 1 year of age, prophylaxis start can be delayed in families from a low social and cultural background and also some families can be reluctant to start treatment in children who still remain asymptomatic. Other reasons remain vaguely determined.

Prophylaxis among our 475 adult severe HA patients ( $>14$ years of age) was unfortunately not so commonly used $(34.7 \%$; 165/475) as in other studies enrolling similar patients like those by Biss et al (53\%) [7] or Plug et al (59.3\%) [9]; this latter analysis includes severe haemophilia A and B patients over the age of 16.

Among our severe HA adult patients, significant differences in the development of EHA were found between those patients receiving prophylactic treatment versus patients receiving on demand treatment. This data are concordant with those published by Aledort et al in 1994 [15]; they found that after 6 years of observation, patients under prophylaxis obtained better orthopaedic and radiological scores than patients following on demand therapy even though secondary prophylaxis couldn't impede the progression of the EHA.

Moreover, in our study we found that primary prophylaxis resulted strongly protective for the adult population.

Although no differences in the degree of joint damage were noticed in the population of severe paediatric patients treated on demand versus those treated with prophylaxis. This results maybe due to the delay on the onset of the secondary prophylaxis in our country. When we did this analysis in function of the type of prophylactic treatment administered, we found that PP resulted protective for the development of EHA in the paediatric population. Early onset of prophylactic treatment is definitely crucial for the 
prevention of EHA. Countries like Holland pioneered wide fostering of such therapeutic approaches in the late sixties [9], long before it became popular in other countries like Spain (where SP began to be used in the late seventies and the PP in the early nineties, approximately) and this may have translated into a steady rate of arthropathy of about $30 \%$, reflected in the Spanish epidemiological study [1]. In our experience the most commonly affected joints were ankles followed by knees and elbows.

Patients for whom a CVAD insertion was decided were more commonly those on PP, which is not surprising considering that patients in this group are more often children under the age of 2 for whom recurrent intravenous infusions via peripheral veins is impractical and may seriously jeopardise compliance with regular prophylaxis.

Data collected from our study disclose that about one in four of our patients on PP (23.5\%) had a CVAD inserted for this purpose, which is similar to rates previously reported by Valentino et al [16]; other research groups however are far more active in the usage of such devices in patients on PP who have one inserted in up to $82 \%$ of cases according to Blanchette et al $[10,14]$.

Major complications of CVAD are infrequent [16]. As already mentioned above catheter associated infections are the most frequent amongst these patients for whom frequencies of 0.28 to 1.6 patient days for individuals without inhibitors have been published up to 2003 [17]. Thus our infection rate (0.73 per 1000 patient days) lies within the range just mentioned. No cases of catheter-triggered thrombosis have been collected from our study, consistently with data from the paper by Ljung et al [18] enrolling a similar number of patients with a CVAD. Malfunctioning frequencies in this study were $18.8 \%$ during an average follow-up period of 13 months, not far from our $13.8 \%$ in a one-year follow-up time.

\section{CONCLUSIONS}

Spanish HA patients and, more specifically severe subjects, are at the same level as most developed countries regarding implementation of therapeutic strategies involving prophylaxis. However information derived from our current research shows some aspects of the management of patients with haemophilia in Spain which might be improved. For instance the reasons leading to a lower rate of prescription of PP or SP in adulthood, as well as the higher frequency of EHA in patients in this group of age must be taken into account. Both issues are probably related to a historic delay in the introduction of PP treatments on a routine basis in our country. 
Therefore, we must strongly stress the importance of adopting early PP schedules in order to avoid serious bleeding episodes as well as the triggering and development of degenerative joint damage. The status of EHA noticed in adult patients with haemophilia along with growing age of this population will unavoidably mean a higher need for orthopaedic procedures of joint replacement in the future.

Acknowledgements: This study was supported by a Wyeth Spain (now Pfizer) grant. We thank Dr. Carlos Aguilar for his help in the translation and the critical revision of the manuscript.

This work was possible thanks to the collaboration of investigators from the 51 participating hospitals: La Paz (F Hernández, M Quintana, I Fernández), La Fe (S Haya, AR Cid, F Querol), Vírgen del Rocío (R Nuñez), Miguel Servet (F Lucía), N. Sra de las Nieves (M J J Gutierrez), Cruces (G Iruin), Xeral-Cíes (R González), Vírgen de la Arrixaca (F García), Río Hortega (JI Tortosa), Carlos Haya (E Mingot), Juan Canalejo (F López), N. Sra Candelaria (J García-Talavera), Puerta del Mar (FJ Rodríguez), Dr Negrín (I Balda), Reina Sofía (F Velasco), Univ. Salamanca (JR González), Montecelo (R Vázquez), Donostia (M Uranga), N. Sra Covadonga (I Soto), Virgen del Camino (M Redondo), Torrecárdenas (B Domínguez), S. Pedro de Alcántara (N Bermejo), Materno-Infantil Málaga (A Palomo), General de Jerez (R Campos), Sant Joan de Deu (T Toll), General Ciudad de Jaén (M Nieto), Joan XXIII (Mª Ugarriza), Marqués de Valdecilla (C Sedano), Santa Bárbara (A Foncillas), Infanta Cristina (R Vaca), General Guadalajara (B Pinedo), Juan Ramón Jiménez (A Amian), Puerto Real (M Monje), Materno Infantil Las Palmas (M Negrín), General Yagu“e (M Prieto), Son Dureta (JF Alvarez), Txagorritxu (R Hernández), N. Sra Cristal (JA Golpe), Santa Ana (F Hernández), Punta de Europa (LA Casaus), San Millán (P Rabasa), Xeral Lugo (A Cobas), Comarcal D. Benito-Villanueva (A Rodríguez), General Insalud Soria (C Aguilar), La Línea (M González), Clínico de Santiago (S Pérez)., N Sra Alarcos (M Tomás), María Inmaculada (AM Navarro), Arquitecto Marcide (C García), General Castellón (IM García) y Santiago Apóstol (E Navarro). 


\section{TABLES:}

Table 1: Type of treatment in HA patients in relation to the degree of severity of haemophilia and age group

\begin{tabular}{|c|c|c|c|c|c|c|c|c|c|c|c|c|c|}
\hline \multirow{2}{*}{\multicolumn{2}{|c|}{ Haemophilia A }} & \multicolumn{4}{|c|}{ Paediatric patients } & \multicolumn{4}{|c|}{ Adult patients } & \multicolumn{4}{|c|}{ Total patients } \\
\hline & & $\begin{array}{l}\text { Mild } \\
\mathrm{n}(\%)\end{array}$ & $\begin{array}{c}\text { Moderate } \\
\mathrm{n}(\%)\end{array}$ & $\begin{array}{c}\text { Severe } \\
n(\%)\end{array}$ & $\begin{array}{l}\text { Total } \\
\mathrm{n}(\%)\end{array}$ & $\begin{array}{l}\text { Mild } \\
\mathrm{n}(\%)\end{array}$ & $\begin{array}{c}\text { Moderate } \\
\mathrm{n}(\%)\end{array}$ & $\begin{array}{c}\text { Severe } \\
\mathrm{n}(\%)\end{array}$ & $\begin{array}{l}\text { Total } \\
\mathrm{n}(\%)\end{array}$ & $\begin{array}{l}\text { Mild } \\
\mathrm{n}(\%)\end{array}$ & $\begin{array}{c}\text { Moderate } \\
\mathrm{n}(\%)\end{array}$ & $\begin{array}{c}\text { Severe } \\
\mathrm{n}(\%)\end{array}$ & $\begin{array}{l}\text { Total } \\
\mathrm{n}(\%)\end{array}$ \\
\hline \multicolumn{2}{|c|}{ Total Patients } & $\begin{array}{c}207 \\
(43.7)\end{array}$ & $\begin{array}{c}60 \\
(12.7)\end{array}$ & $\begin{array}{c}207 \\
(43.7)\end{array}$ & $\begin{array}{c}474 \\
(22.8)\end{array}$ & $\begin{array}{c}902 \\
(31.4)\end{array}$ & $\begin{array}{c}230 \\
(14.3)\end{array}$ & $\begin{array}{c}475 \\
(29.6)\end{array}$ & $\begin{array}{l}1607 \\
(77.2)\end{array}$ & $\begin{array}{l}1109 \\
(53.3)\end{array}$ & $\begin{array}{c}290 \\
(13.9)\end{array}$ & $\begin{array}{c}682 \\
(32.8)\end{array}$ & $\begin{array}{l}2081 \\
(100)\end{array}$ \\
\hline \multicolumn{2}{|c|}{$\begin{array}{l}\text { Total Patients on } \\
\text { Treatment }\end{array}$} & $\begin{array}{c}80 \\
(38.6)\end{array}$ & $\begin{array}{c}\mathbf{5 4} \\
(90)\end{array}$ & $\begin{array}{c}198 \\
(95.7)\end{array}$ & $\begin{array}{c}332 \\
(67.1)\end{array}$ & $\begin{array}{c}283 \\
(31.4)\end{array}$ & $\begin{array}{c}180 \\
(78.3)\end{array}$ & $\begin{array}{c}433 \\
(91.2)\end{array}$ & $\begin{array}{c}896 \\
(55.8)\end{array}$ & $\begin{array}{c}363 \\
(32.7)\end{array}$ & $\begin{array}{c}234 \\
(80.7)\end{array}$ & $\begin{array}{c}631 \\
(92.5)\end{array}$ & $\begin{array}{l}1228 \\
(59)\end{array}$ \\
\hline \multirow[t]{4}{*}{$\begin{array}{l}\text { Type of } \\
\text { Treatment }\end{array}$} & NR $¥$ & $\begin{array}{c}2 \\
(2.5)\end{array}$ & $\begin{array}{c}0 \\
(0)\end{array}$ & $\begin{array}{c}3 \\
(1.5)\end{array}$ & $\begin{array}{c}5 \\
(1.5)\end{array}$ & $\begin{array}{c}6 \\
(2.1)\end{array}$ & $\begin{array}{c}4 \\
(2.2)\end{array}$ & $\begin{array}{c}1 \\
(0.2)\end{array}$ & $\begin{array}{c}11 \\
(1.2)\end{array}$ & $\begin{array}{c}8 \\
(2.2)\end{array}$ & $\begin{array}{c}4 \\
(1.7)\end{array}$ & $\begin{array}{c}4 \\
(0.6)\end{array}$ & $\begin{array}{c}\mathbf{1 6} \\
(1.3)\end{array}$ \\
\hline & On demand & $\begin{array}{c}68 \\
(85)\end{array}$ & $\begin{array}{c}28 \\
(51.9)\end{array}$ & $\begin{array}{c}47 \\
(23.7)\end{array}$ & $\begin{array}{c}143 \\
(43.1)\end{array}$ & $\begin{array}{l}266 \\
(94)\end{array}$ & $\begin{array}{c}137 \\
(76.1)\end{array}$ & $\begin{array}{c}267 \\
(61.7)\end{array}$ & $\begin{array}{c}670 \\
(74.8)\end{array}$ & $\begin{array}{l}334 \\
(92)\end{array}$ & $\begin{array}{c}165 \\
(70.5)\end{array}$ & $\begin{array}{c}314 \\
(49.8)\end{array}$ & $\begin{array}{c}813 \\
(66.2)\end{array}$ \\
\hline & Prophylaxis & $\begin{array}{c}10 \\
(12.5)\end{array}$ & $\begin{array}{c}26 \\
(48.2)\end{array}$ & $\begin{array}{c}148 \\
(74.8)\end{array}$ & $\begin{array}{c}184 \\
(55.4)\end{array}$ & $\begin{array}{c}11 \\
(3.9)\end{array}$ & $\begin{array}{c}39 \\
(21.7)\end{array}$ & $\begin{array}{c}165 \\
(38.1)\end{array}$ & $\begin{array}{l}215 \\
(24)\end{array}$ & $\begin{array}{c}21 \\
(5.8)\end{array}$ & $\begin{array}{c}65 \\
(27.8)\end{array}$ & $\begin{array}{c}313 \\
(49.6)\end{array}$ & $\begin{array}{c}399 \\
(32.5)\end{array}$ \\
\hline & Total & 80 & 54 & 198 & 332 & 283 & 180 & 433 & 896 & 363 & 234 & 631 & 1228 \\
\hline
\end{tabular}

$¥$ NR: Not recorded in the case report form the type of treatment followed by the patient (on demand or prophylaxis) 
Table 2: Type of prophylaxis in HA patients in relation to the degree of severity of haemophilia and age group

\begin{tabular}{|c|c|c|c|c|c|c|}
\hline & \multicolumn{3}{|c|}{ Severity } & \multicolumn{2}{|c|}{ Age group } & \multirow[b]{2}{*}{$\begin{array}{l}\text { Total } \\
\text { n }(\%)\end{array}$} \\
\hline $\begin{array}{l}\text { Type of } \\
\text { prophylaxis }\end{array}$ & $\begin{array}{l}\text { Mild } \\
\text { n (\%) }\end{array}$ & $\begin{array}{r}\text { Moderate } \\
\mathrm{n}(\%)\end{array}$ & $\begin{array}{l}\text { Severe } \\
\mathrm{n}(\%)\end{array}$ & $\begin{array}{r}\text { Paediatric } \\
\text { n }(\%)\end{array}$ & $\begin{array}{l}\text { Adult } \\
\mathrm{n}(\%)\end{array}$ & \\
\hline Undetermined & $3(14.3)$ & $3(4.6)$ & $9(2.9)$ & 9 (4.9) & $6(2.8)$ & $15(3.8)$ \\
\hline $\mathrm{APP} *$ & 0 & $4(6.2)$ & $32(10.2)$ & $28(15.2)$ & $8(3.7)$ & $36(9)$ \\
\hline BPP \# & $4(19.1)$ & $3(4,6)$ & $38(12.1)$ & $40(21.7)$ & $5(2.3)$ & $45(11.3)$ \\
\hline ASP \# & $6(28.6)$ & $35(53.9)$ & $165(52.7)$ & $88(47.8)$ & $118(54.9)$ & $206(51.6)$ \\
\hline זئ BSP & $8(38.1)$ & $20(30.8)$ & $69(22)$ & $19(10.3)$ & $78(36.3)$ & $97(24.3)$ \\
\hline TOTAL & $21(100)$ & $65(100)$ & $313(100)$ & $184(100)$ & $215(100)$ & $399(100)$ \\
\hline
\end{tabular}

(*) APP: A Primary Prophylaxis

(\#) BPP: B Primary Prophylaxis

(\#) ASP: A Secondary Prophylaxis

(先) BSP: B Secondary Prophylaxis 
Table 3: Type of prophylactic treatment in HA patients of different age groups

\begin{tabular}{|c|c|c|c|c|c|c|c|c|}
\hline & \multicolumn{4}{|c|}{ Paediatric patients $(<14$ years) } & \multicolumn{4}{|c|}{ Adult patients ( $\geq 14$ years) } \\
\hline $\begin{array}{ll}\text { Type } & \text { of } \\
\text { prophylaxis }\end{array}$ & $\begin{array}{l}\text { Mild } \\
\text { n (\%) }\end{array}$ & $\begin{array}{r}\text { Moderate } \\
\mathrm{n}(\%)\end{array}$ & $\begin{array}{l}\text { Severe } \\
\mathrm{n}(\%)\end{array}$ & $\begin{array}{l}\text { Total } \\
\mathrm{n}(\%)\end{array}$ & $\begin{array}{l}\text { Mild } \\
\text { n (\%) }\end{array}$ & $\begin{array}{r}\text { Moderate } \\
\mathrm{n}(\%)\end{array}$ & $\begin{array}{l}\text { Severe } \\
\mathrm{n}(\%)\end{array}$ & $\begin{array}{l}\text { Total } \\
\text { n }(\%)\end{array}$ \\
\hline Undetermined & $2(20)$ & $1(3.9)$ & $6(4.1)$ & $9(4.9)$ & $1(9.1)$ & $2(5.1)$ & $3(1.8)$ & $6(2.8)$ \\
\hline $\mathrm{APP} *$ & 0 & $2(7.7)$ & $26(17.6)$ & $28(15.2)$ & 0 & $2(5.1)$ & $6(3.6)$ & 8 (3.7) \\
\hline BPP \# & $3(30)$ & $3(11.5)$ & $34(23)$ & $40(21.7)$ & $1(9.1)$ & 0 & $4(2.4)$ & $5(2.3)$ \\
\hline ASP \# & $3(30)$ & 14 (53.9) & $71(48)$ & $88(47.8)$ & $3(27.3)$ & $21(53.9)$ & 94 (57) & $118(54.9)$ \\
\hline $\mathrm{BSP}$ & $2(20)$ & $6(23.1)$ & $11(7.4)$ & $19(10.3)$ & $6(54.6)$ & $14(35.9)$ & $58(35.2)$ & $78(36.3)$ \\
\hline TOTAL & $10(100)$ & $26(100)$ & $148(100)$ & $184(100)$ & $11(100)$ & $39(100)$ & $165(100)$ & $215(100)$ \\
\hline
\end{tabular}

(*) APP: A Primary Prophylaxis

(\#) BPP: B Primary Prophylaxis

(\#) ASP: A Secondary Prophylaxis

(岁) BSP: B Secondary Prophylaxis 
Table 4: Established Haemophilic Arthropathy in relation to age and type of prophylaxis

\begin{tabular}{|c|c|c|c|c|}
\hline \multirow{3}{*}{\multicolumn{2}{|c|}{ Haemophilia A }} & \multicolumn{3}{|c|}{ Established Haemophilic Arthropathy (EHA) } \\
\hline & & \multirow{2}{*}{$\begin{array}{c}\text { Paediatric severe patients } \\
\mathbf{N}(\%)\end{array}$} & \multirow{2}{*}{$\begin{array}{c}\text { Adult severe patients } \\
\mathbf{N}(\%)\end{array}$} & \multirow{2}{*}{$\begin{array}{c}\text { Total severe patients } \\
\mathbf{N}(\%)\end{array}$} \\
\hline & & & & \\
\hline \multicolumn{2}{|l|}{ Treated patients } & $44 / 198(22.2)$ & $322 / 433(74.4)$ & $366 / 631(58 \%)$ \\
\hline \multirow[t]{3}{*}{ Type of treatment } & NR $¥$ & $0 / 3(0)$ & 1/1 (100) & $1 / 4(25)$ \\
\hline & On demand & $11 / 47(23.4)$ & $212 / 267(79.4)$ & $223 / 314(71)$ \\
\hline & On prophylaxis & $33 / 148(22.3)$ & $109 / 165(66.1)$ & $142 / 313(45.4)$ \\
\hline \multirow[t]{5}{*}{ Type of prophylaxis } & NR $¥$ & $0 / 6(0)$ & $2 / 3(66.7)$ & $2 / 9(22.2)$ \\
\hline & $\mathbf{A P P} *$ & $0 / 26(0)$ & $0 / 6(0)$ & $0 / 32(0)$ \\
\hline & BPP \# & $2 / 34(5.9)$ & $0 / 4(0)$ & $2 / 38(5.3)$ \\
\hline & ASP \# & $27 / 71(38)$ & $65 / 94(69.2)$ & $92 / 165(55.8)$ \\
\hline & BSP & $4 / 11(36.4)$ & $42 / 58(72.4)$ & $46 / 69(66.6)$ \\
\hline
\end{tabular}

$¥ \mathbf{N R}$ : Not recorded in the case report form the type of treatment followed by the patient (on demand or prophylaxis)

(*) APP: A Primary Prophylaxis

(\#) BPP: B Primary Prophylaxis

(\#) ASP: A Secondary Prophylaxis

(壱) BSP: B Secondary Prophylaxis 


\section{FIGURES}

Figure 1: Frequency of prophylaxis used in the entire Haemophilia A population and in the severe HA patients.

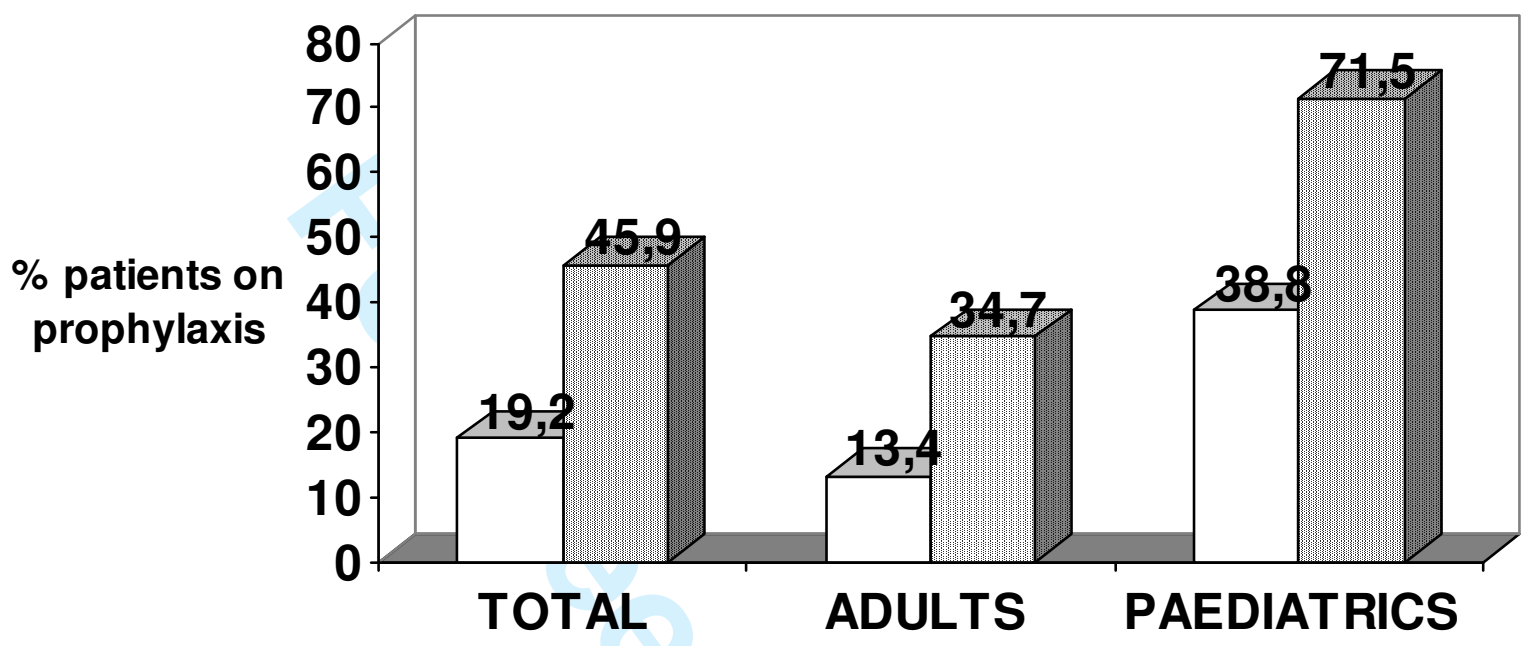

\section{$\square$ TOTAL HA $\square$ TOTAL SEVERE HA}




\section{References.-}

1. Aznar JA, Lucía F, Abad-Franch L, Jiménez-Yuste V, Pérez R, Batlle J, Balda I et al. Haemophilia in Spain. Haemophilia 2009; 15: 665-675.

2. Aznar JA, Abad-Franch L, Cortina VR, Marco P. The national registry of haemophilia A and B in Spain: results from a census of patients. Haemophilia 2009; 15: 1327-1330.

3. Pettersson H, Ahlberg A, Nilsson IM. A radiologic classification of hemophilic arthropathy. Clin Orthop Relat Res 1980: 153-9

4. Hacker MR, Geraghty S, Manco-Johnson M. Barriers to compliance with prophylaxis therapy in haemophilia. Haemophilia 2001; 7: 392-396.

5. White GC, Rosendaal F, Aledort LM, Lusher JM, Rothschild C, Ingerslev J. Definitions in haemophilia. Recommendation of the scientific subcommittee on factor VIII and factor IX of the Scientific and Standardization Committee of the International Society on Thrombosis and Haemostasis. Thromb Haemost 2001; 85: 560.

6. Donadel-Claeyssens S. Current co-ordinated activities of the PEDNET (European Paediatric Network for Haemophilia Management). Haemophilia 2006; 12: 124-127.

7. Biss TT, Chan AK, Blanchette V. The use of prophylaxis in 2663 children and adults with haemophilia: results of the 2006 Canadian national haemophilia prophylaxis survey. Haemophilia 2008; 14: 923-930.

8. Larsson SA, Nilsson IM, Blomback M. Current status of Swedish haemophiliacs. A demographic survey. Acta Med Scand 1982; 212: 195-200.

9. Plug I, van der Bom JG, Peters M, Mauser-Bunschoten EP, de Goede-Bolder A, Heijnen L, et al. Thirty years of haemophilia treatment in the Netherlands, 1972-2001. Blood 2004; 14: 3494-3500.

10. Butler RB, McClure W, Wulff K. Practice patterns in haemophilia A therapy- a survey of treatment centres in the United States. Haemophilia 2003; 9: 549-554.

11. Windyga J, Lopaciuk S, Stefanska E, Juszynski A, Wozniak D, Strzelecki O, Szczepanik AB. Haemophilia in Poland. Haemophilia 2006; 12: 52-57.

12. Ono O, Suzuki Y, Yosikawa K, Wada I, Doi Y, Takano M, Wada Y et al. Assessment of haemophilia treatment practice pattern in Japan. Haemophilia 2009; 15: 1032-1038. 
13. Taki M, Shirahata A. Current situation of regular replacement therapy (prophylaxis) for haemophilia in Japan. Haemophilia 2009; 15: 78-82.

14. Blanchette VS, McCready M, Achonu C, Abdolell M, Rivard G, Manco-Johnson MJ. A survey of factor prophylaxis in boys with haemophilia followed in North American haemophilia treatment centres. Haemophilia 2003; 9 (Suppl 1): 19-26; discussion.

15. Aledort LM, Haschmeyer RH, Pettersson H. A longitudinal study of orthopaedic outcomes for severe factor-VIII-deficient haemophiliacs. The Orthopaedic Outcome Study Group. J Intern Med 1994;236(4):391-399

16. Valentino LA, Ewenstein B, Navickis RJ, Wilkes MM. Central venous access devices in haemophilia. Haemophilia 2004; 10: 134-146.

17. Ljung R. Central venous lines in haemophilia. Haemophilia 2003; 9 (Suppl 1): 88-92; discussion 3.

18. Ljung R, van den Berg M, Petrini P, Tengborn L, Scheibel E, Kekomäki R et al. Port-A-Cath usage in children with haemophilia: experience of 53 cases. Acta Paediatr 1998; 87: 1051-1054. 